\title{
Sabar dalam Perspektif Islam dan Barat
}

\author{
M. Yusuf \\ Sekolah Tinggi Agama Islam Auliaurrasyidin Riau \\ E-mail: Ibnusalam27@gmail.com \\ Dona Kahfi, MA. Ibala \\ Fakultas Ushuluddin, UIN Syarif Kasim Riau \\ E-mail: d kahfie@yahoo.com \\ Moh. Toriqul Chaer \\ STIT Islamiyah Karya Pembangunan Paron, Ngawi \\ Email: toriqul_74@yahoo.com
}

\begin{abstract}
: advances in science and technology are like two sides of the coin, it could be a disaster, while humans are not ready and hasn't been able to go with the flow of such changes. Inability to adjust to these changes can give rise to tension or stress on him. The teachings of Islam with universal, covering all the dimensions of human life, including problems of human material or mental (psychic). Patient in facing changes the massif became a strategic point to develop human capacity to explore change the world. Education patience recorded in Q. S al-Baqarah verse 45, 153, 294 and aliImran, verse $125,186,200$. On the other hand the patience had the function as a solution of the problem, people who implement the problematic nature of the patient will feel easy through obedience to God and his Messenger. Wait as the system of psychological defense mechanism to cope with the dynamic test faced by man as God's Caliphs on Earth. Patient in the Western perspective is known for its patient and patience, and have some other equivalent variants, among them; 1) self-control; 2) Resiliensi; Perseverence. 3); 4) Acceptence
\end{abstract}

Keywords: as-sabr; Perspective, Islam and the West

\section{Pendahuluan}

Konsep sabar dalam al-Quran menjadi salah satu bahasan ulama yang cukup menarik dan penting. Disamping karena terakait dengan masalah teologi juga terkait dengan apek sosial masyarakat. Kajian al-Quran tentang sabar biasanya menjadi salah satu bentuk kajian tafsir maudhui, dan ini sudah banyak dilakukan. Tulisan ini menggunakan pendekatan yang sama, hanya saja menggunakan paradigma keilmuan integralistik, dan mencoba mengaitkannya dengan pendekatan Psikologi Islam, serta membandingkan dengan psikologi barat. ${ }^{1}$

${ }^{1}$ Sabar merupakan kata yang mengacu pada nilai sabar yang merupakan salah satu nilai positif (virtue) yang diyakini oleh masyarakat secara umum. Penelitian yang dilakukan oleh Subandi (2011), menyebutkan bahwa nilai sabar merupakan nilai yang dianjurkan oleh banyak agama dengan beberapa variasi dalam detail penjelasannya, lihat selengkapnya dalam Subhan El Hafiz, Psikologi Kesabaran, Buletin Konsorsium Psikologi Ilmiah Nusantara, ISSN 2477-1686, Vol. 1., No. 2, November 2015 
Pesatnya perkembangan psikologi saat ini, membuat psikologi, terutama psikologi positif mulai melirik nilai-nilai yang terdapat pada belahan dunia timur, tidak terkecuali nilai-nilai yang terkandung dalam ajaran Islam. Dalam kerangka pemikiran inilah kemudian tulisan ini, dengan segala keterbatasannya dihadirkan.

Kata sabar dengan seluruh derivasinya ditemukan sekitar 123 kali dalam alQuran yang tersebar pada surah Makkiyah dan Madaniyah. Meskipun sebagian ulama memberikan perhitungan yang berbeda, akan tetapi perbedaan itu dapat dikompromikan dengan melihat sebab perbedaan tersebut. Ulama berbeda cara pandangnya untuk menghitung satu ayat yang memuat dua atau tiga kata sabar. Jika jumlah ayat yang di dalamnya terdapat kata sabar dihitung, maka akan berbeda dengan seluruh kata sabar yang terdapat dalam al-Quran karena ada satu ayat yang mengandung dua atau tiga kata sabar.

Konsep sabar bisa dikategorisasikan sebagai salah satu topik kajian dalam psikologi positif, seperti halnya kebersyukuran (gratitude) dan pemaafan (forgiveness). Literatur yang berkaitan dengan pemaafan (forgiveness) telah cukup banyak berkembang di Barat (Enrigh, 2009). Di Indonesia topik pemaafan juga sudah mulai banyak dikaji (Subandi dkk., 2010; Rahmandani, 2010; Zuhdiyati, 2010). Demikian juga topik kebersyukuran (gratitude) sudah menjadi kajian dalam berbagai literatur (Emmon \& McCullough, 2004; Krause, 2006). ${ }^{2}$ Konsep ‘sabar' pada umumnya dikaji dalam konteks moralitas dan religius. Misalnya orang harus sabar menghadapi cobaan, orang harus sabar dalam taat menjalankan perintah agama dan menjauhi larangan agama (Asma, 2010; Turfe, 2009).

\section{Pembahasan}

\section{A. Sabar dalam Pandangan Islam}

Sabar adalah salah satu unsur internal yang dimiliki oleh setiap manusia. Meskipun term ini dipersilisihkan oleh kalangan intelektual tentang posisinya dalam manusia. Sebagian mereka mengatakan bahwa sabar adalah sikap yang dimiliki oleh setiap orang dan sebagian lain condong mengatakan bahwa sabar adalah sifat yang melekat pada diri seseorang. Lebih dari itu, term ini diperdebatkan tentang eksistensinya. Sebagian kalangan mengatakan bahwa

${ }^{2}$ Subandi, Sabar: Sebuah Konsep Psikologi, Fakultas Psikologi, Universitas Gadjah Mada dalam Jurnal Psikologi, Volume 38, No. 2, Desember 201l: 215 - 227 
setiap orang secara fitrah memiliki unsur tersebut dan sebagian yang lain mengatakan bahwa unsur ini timbul-tenggelam dalam diri manusia.

Secara etimologi kata sabar pada awalnya diartikan sebagai "menahan pada tempat yang sempit". ${ }^{3}$ Selanjutnya, jika kata sabar dikaitkan dengan manusia, maka dapat berarti menahan jiwa dari hal-hal yang dapat dibenarkan oleh logika dan wahyu. ${ }^{4}$ Lafadz sabar merupakan lafadz yang umum. Lafadz ini dapat berkembang maknanya sesuai dengan redaksi kalimat yang merangkai kata sabar tersebut. ${ }^{5}$ Sedangkan Ibn Faris menulis bahwa kata sabar memiliki tiga makna, yaitu: pertama, membelenggu; kedua, ujung tertinggi dari sesuatu; ketiga, jenis batu-batuan. ${ }^{6}$

Menurut Hamka Hasan, pengertian tersebut di atas mengindikasikan bahwa kata sabar secara etimologi dapat dipahami sebagai proses yang "aktif" bukan "pasif". Proses yang aktif adalah sebuah proses yang bergerak dalam satu ruang dan waktu. Sabar dapat terealisasikan jika ada proses yang aktif untuk "menahan", "membelenggu" dan "menutup". Jika hal ini dilakukan secara aktif, maka proses ini akan berujung pada sebuah hasil yang disebut sebagai sabar. ${ }^{7}$

Kata sabar dengan aneka ragam derivasinya ditemukan makna yang beragam antara lain: shabara bih yang berarti "menjamin". Shabîr yang berarti "pemuka masyarakat yang melindungi kaumnya". Dari akar kata tersebut terbentuk pula kata yang berarti "gunung yang tegar dan kokoh”, “awan yang berada di atas awan lainnya sehingga melindungi apa yang terdapat di bawahnya", "batu-batu yang kokoh", "tanah yang gersang”, "sesuatu yang pahit atau menjadi pahit". Dengan pengertian-pengertian ini, Quraish Shihab menyimpulkan bahwa sebuah kesabaran menuntut ketabahan menghadapi

\footnotetext{
${ }^{3}$ Arti menahan ini diperoleh dari kata al-Imsaak

4 Sabar dengan pengertian "menahan" dapat berarti fisik material seperti menahan seseorang dalam tahanan/ kurungan dan dapat berarti non fisik/ immaterial seperti menahan diri/ jiwa dalam menghadapi sesuatu yang diinginkannya.

5 Ar-Raghib al-Ashfahani, Mufradât al-Fâdz al-Quran, edisi. Shafwan Adnan Dawudi, (Damsykus: Dar al-Qalam,1992 M/1412 H), h. 474-475.

${ }^{6}$ Ibn Faris, Mu'jam Maqâyîs al-Lughah, (Beirut: Dar al-Fikr, t.th), Juz III, H. 3249-330.

${ }^{7}$ Hamka Hasan, "Hakikat Sabar dalam Al-Qur'an (Kajian Tematik dalam Surah alBaqarah), dalam Jurnal Bimas Islam, Vol. 6 No. 2, 2013, h. 215, 232.
} 
sesuatu yang sulit, berat, pahit, yang harus diterima dan dihadapi dengan penuh tanggung jawab. ${ }^{8}$

Achmad Mubarok mendefinisikan sabar sebagai tabah hati tanpa mengeluh dalam menghadapi godaan dan rintangan dalam jangka waktu tertentu dalam rangka mencapai tujuan. ${ }^{9}$ Karena sabar bermakna kemampuan mengendalikan emosi, maka nama sabar berbeda-beda tergantung objeknya ${ }^{10}$ :

1. Ketabahan menghadapi musibah, disebut sabar, kebalikannya adalah gelisah dan keluh kesah

2. Kesabaran menghadapi godaan hidup nikmat disebut mampu menahan diri (dhobith an nafs), kebalikannya adalah tidaktahanan (bathar)

3. Kesabaran dalam peperangan disebut pemberani, kebalikannya disebut pengecut

4. Kesabaran dalam menahan marah disebut santun (hilm), kebalikannya disebut pemarah (tazammur)

5. Kesabaran dalam menghadapi bencana yang mencekam disebut lapang dada, kebalikannya disebut sempit dadanya

6. Kesabaran dalam mendengar gosip disebut mampu menyembunyikan rahasia

7. Kesabaran terhadap kemewahan disebut zuhud, kebalikannya disebut serakah

8. Kesabaran dalam menerima yang sedikit disebut kaya hati (qana'ah) kebalikannya disebut tamak atau rakus.

Dari pengertian-pengertian di atas, dapat dirumuskan bahwa sabar secara terminologi memiliki makna sebagai "upaya menahan diri/ membatasi jiwa dari keinginannya demi mencapai sesuatu yang lebih baik/ luhur.”

\footnotetext{
${ }^{8}$ Quraish Shihab, Tafsir al-Amanah, Indonesia: Pustaka Kartini, 1992 M/1413 H, Cet. I, h. 11l. Pembacaan lebih lanjut mengenai sabar dalam dijumpai pada beberapa kitab klasik, diantaranya Al Ghazali, salah satu ulama klasik dalam agama Islam telah membahas masalah sabar dan kesabaran dalam kitab Sabar dan Syukur yang menjadi bagian dari kitab Ihya Ulumuddin. Demikian juga Ibnul Qoyyim Al Jauziah menulis kitab berjudul Uddatu As Shobirin Wa Dzkirotu Asy Syakirin, yang diterjemahkan dalam bahasa Indonesia dengan judul"Indahnya Kesabaran"

${ }_{9}^{9}$ Ahmad Mubarok, Psikologi Qur'ani, (Jakarta: Pustaka Firdaus, 2001), h. 73.

${ }^{10}$ Objek di sini sama dengan "menghadapi sesuatu" yang sulit, berat, dan pahit dalam pandangan Quraish Shihab sebelumnya.
} 


\section{B. Dimensi dan Pembagian Sabar}

Quraish Shihab, dalam Tafsir Al-Mishbah, menjelaskan bahwa sabar artinya menahan diri dari sesuatu yang tidak berkenan di hati. Ia juga berarti ketabahan. Selain itu, ia menjelaskan bahwa kesabaran secara umum dibagi menjadi dua. Pertama, sabar jasmani yaitu kesabaran dalam menerima dan melaksanakan perintah-perintah keagamaan yang melibatkan anggota tubuh seperti sabar dalam menunaikan ibadah haji yang menyebabkan keletihan. Termasuk pula, sabar dalam menerima cobaan jasmaniyah seperti penyakit, penganiayaan dan sebagainya. Kedua, sabar rohani menyangkut kemampuan menahan kehendak nafsu yang dapat mengantar kepada kejelekan semisal sabar dalam menahan amarah, atau menahan nafsu seksual yang bukan pada tempatnya.

Pendapat Quraish Shihab, sama dengan apa yang telah disampaikan oleh Ibnu al-Qayyim bahwa sabar, berdasarkan bentuknya terdiri dari dua macam, kesabaran jasmani dan kesabaran jiwa. ${ }^{11}$ Kesabaran jasmani dibagi menjadi dua: 1) kesabaran jasmani secara sukarela, misalnya sabar dalam melakukan pekerjaan berat atas pilihan dan kehendaknya sendiri dan 2) kesabaran jasmani oleh faktor keterpaksaan, misalnya sabar dalam menahan rasa sakit akibat pukulan, sabar menahan penyakit, menahan dingin, panas dan sebagainya.

Sebagaimana kesabaran jasmani, kesabaran jiwa juga dibagi menjadi dua macam, yakni: 1) Kesabaran jiwa secara sukarela, misalnya kesabaran menahan diri untuk melakukan perbuatan yang tidak baik berdasarkan pertimbangan syariat agama dan akal; dan 2) Kesabaran jiwa oleh faktor keterpaksaan, seperti kesabaran berpisah dengan orang yang dikasihi jika cinta terhalang.

Kata sabar, sebagaimana telah disinggung pada bagian pendahuluan ditemukan sekitar 123 kali dalam Al-Quran yang tersebar pada surah Makkiyah dan Madaniyah. Meskipun sebagian diantara ulama memberikan perhitungan

${ }^{11}$ Ibnu al-Qayyim al-Jauziyyah mengemukakan, sabar adalah menahan jiwa untuk tidak berkeluh kesah, menahan lisan untuk tidak meratap dan menahan untuk tidak menampar pipi, merobek baju dan sebagainya. Lihat selengkapnya dalam Ibnu al-Qayyim Al-Jauziyyah, alihbahasa oleh A.M. Halim 'Uddatu Ash-Shabirin wa Dzakhiratu asy-Syakirin, (Jakarta: Maghfirah Pustaka, 2006), h. 37. 
yang berbeda seperti Imam Al-Gazali menyebutkan sekitar $70 \mathrm{kali}^{12}$, Ibnul Qayyim mengutip perkataan imam Ahmad: "sabar" didalam al-Qur'an terdapat di sekitar 90 tempat; Abu Thalib al-Makki menyebutkan $90 \mathrm{kali}^{13}$, sementara Muhammad Fuad Abdul Baqi menyebutkan 102 kali. $^{14}$ Didalam al-Mu'jam alMufahras li alfadz al-Qur'an, asal kata disebutkan di dalam al-Qur'an lebih dari 100 kali.

Jumlah kata sabar dalam Al-Quran beragam, namun keragaman itu dapat dikompromikan dengan melihat sebab perbedaan tersebut. Ulama berbeda cara pandangnya untuk menghitung satu ayat yang memuat dua atau tiga kata sabar. Jika jumlah ayat yang di dalamnya terdapat kata sabar dihitung, maka akan berbeda dengan seluruh kata sabar yang terdapat dalam Al-Quran karena ada satu ayat yang mengandung dua atau tiga kata sabar. Perintah untuk bersabar, sangat banyak di dalam al-Qur'an, ${ }^{15}$ misalnya pada QS. (2): 153

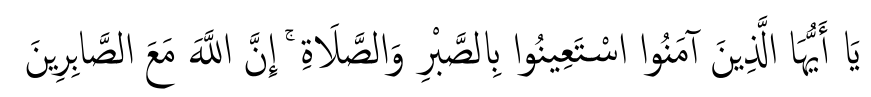

Artinya: "Hai orang-orang yang beriman, Jadikanlah sabar dan shalat sebagai penolongmu, Sesungguhnya Allah beserta orang-orang yang sabar."

Al-Qur'an menggambarkan beberapa cara untuk membiasakan sikap sabar, antara lain adalah dengan:

1. Menanamkan keyakinan adanya balasan yang baik bagi orang-orang yang sabar. Keyakinan semacam ini merupakan sesuatu hal yang sangat penting membantu seseorang agar dapat bersifat sabar. Dalam hal ini Abu Thalib alMakky, mengatakan bahwa penyebab utama kurangnya kesabaran seseorang itu adalah akibat lemahnya keyakinan akan adanya balasan yang baik bagi orang-orang yang sabar.

2. Mengingatkan bahwa orang yang paling dekat dengan Allah pun, seperti nabi dan rasul senantiasa memperoleh cobaan, bahkan bentuk cobaannya lebih berat lagi dibandingkan dengan kebanyakan manusia, misalnya ketika

\footnotetext{
${ }^{12}$ Imam al-Gazali, Ihya 'Ulum ad-Din,(Beirut: Dar Ma’rifah, 1990 M), Juz IV, h. 61

${ }^{13}$ Ibn Qayyim, Madarij as-Salikin, (Cairo: Dar Salam, t.th), Juz II, h. 121. Abu Thalib alMakki, Qauth al-Qulub, (Cairo: Dar al-halabi, t.th), Juz I, h. 197.

${ }^{14}$ Muhammad Fuad Abdul Baqi, al-Mu'jam al-Mufahras li Alfadz al-Qur'an al-Karim, (Cairo: Dar al-hadits, 1364), h. 399-401.

${ }^{15}$ Ayat-ayat lain yang serupa mengenai perintah untuk bersabar, diantaranya terdapat pada QS.3 : $200,16: 127,8: 46,10: 109,11: 115$
} 
Allah membesarkan hati Nabi Muhammad SAW (QS. [6]: 34; QS. [46]: 35; QS. [38]: 44).

3. Menanamkan keyakinan adanya kemudahan setelah kesusahan, dan janjijanji Allah tersebut sebagai suatu kepastian. Misalnya firman Allah: QS. alInsyirah [94]: 5-6;

4. Menanamkan kesadaran, bahwa manusia itu milik Allah. Dialah yang memberi kehidupan, gerak, perasaan, pendengaran, penglihatan, hati, dan sebagainya, serta menganugerahkan kepadanya segala nikmat yang ada pada dirinya berupa harta, anak, keluarga, dan sebagainya. (QS. [16]: 53).

5. Mengingatkan adanya sunnatullah atau hukum alam yang berlaku di dunia ini seperti dalam firman-Nya (QS. [3]: 140). Dalam al-Qur'an, antara lain dikemukakan: "Tiada suatu bencana yang menimpa di bumi dan (tiada pula) pada dirimu sendiri melainkan telah tertulis dalam kitab (Lauh Mahfudz) sebelum Kami menciptakannya. Sesungguhnya yang demikian itu adalah mudah bagi Allah. (Kami jelaskan yang demikian itu) supaya kamu jangan berduka cita terhadap apa yang luput dari kamu, dan supaya kamu jangan terlalu gembira terhadap apa yang diberikan-Nya kepadamu...”

6. Menanamkan keyakinan tentang Qada dan Qadar Allah yang tidak mungkin dapat dihindari. (QS. [57]: 22-23).

\section{Larangan tidak Sabar}

Larangan tidak sabar (isti'jal/ tergesa-gesa), misalnya terdapat pada QS. Al-Ahqaf (46): 35

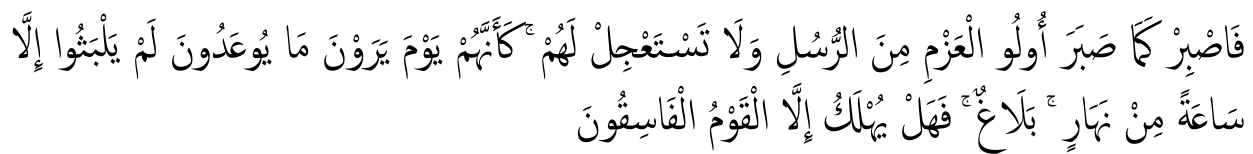

"Maka bersabarlah kamu seperti orang-orang yang mempunyai keteguhan hati dari Rasulrasul telah bersabar dan janganlah kamu meminta disegerakan (azab) bagi mereka. pada hari mereka melihat azab yang diancamkan kepada mereka (merasa) seolah-olah tidak tinggal (di dunia) melainkan sesaat pada siang hari. (inilah) suatu pelajaran yang cukup, Maka tidak dibinasakan melainkan kaum yang fasik."

\section{Reward bagi yang bersabar}

1. Pujian Allah terhadap orang-orang yang sabar Allah memuji orangorang yang benar dalam keimanannya, QS. Al-Baqarah: 177: 


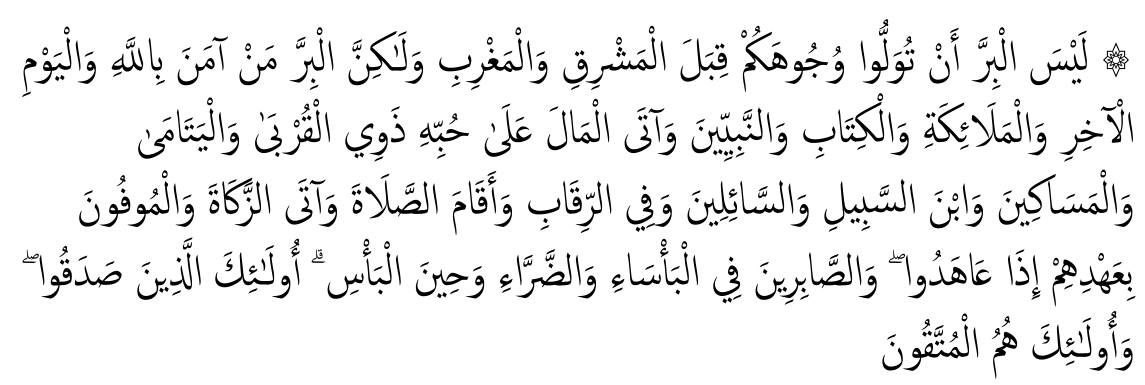

Bukanlah menghadapkan wajahmu ke arah timur dan barat itu suatu kebajikan, akan tetapi sesungguhnya kebajikan itu ialah beriman kepada Allah, hari kemudian, malaikat-malaikat, kitab-kitab, nabi-nabi dan memberikan harta yang dicintainya kepada kerabatnya, anak-anak yatim, orang-orang miskin, musafir (yang memerlukan pertolongan) dan orang-orang yang meminta-minta; dan (memerdekakan) hamba sahaya, mendirikan shalat, dan menunaikan zakat; dan orang-orang yang menepati janjinya apabila ia berjanji, dan orang-orang yang sabar dalam kesempitan, penderitaan dan dalam peperangan. Mereka itulah orang-orang yang benar (imannya); dan mereka itulah orang-orang yang bertakwa.

2. Allah mencintai orang yang sabar, QS. Al-Imran: 146:

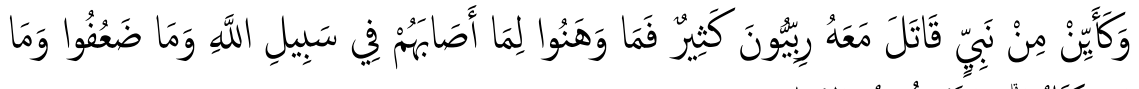

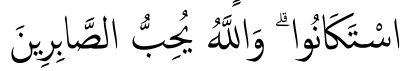

"dan berapa banyaknya Nabi yang berperang bersama-sama mereka sejumlah besar dari pengikut (nya) yang bertakwa. mereka tidak menjadi lemah karena bencana yang menimpa mereka di jalan Allah, dan tidak lesu dan tidak (pula) menyerah (kepada musuh). Allah menyukai orang-orang yang sabar."

3. Mendapat ampunan dari Allah, QS. Hud: 11: 11

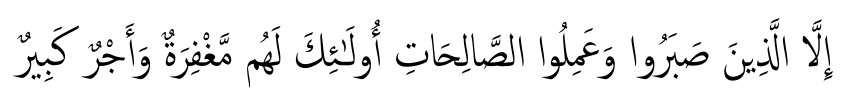

"kecuali orang-orang yang sabar (terhadap bencana), dan mengerjakan amalamal saleh; mereka itu beroleh ampunan dan pahala yang besar."

4. Mendapat martabat yang tinggi di surga QS. 10: 9

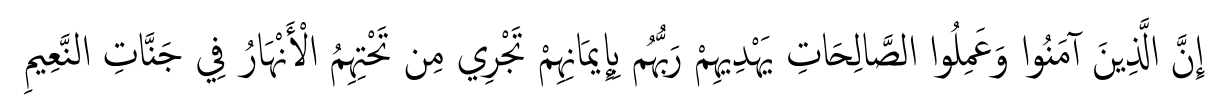

Sesungguhnya orang-orang yang beriman dan mengerjakan amal-amal saleh, mereka diberi petunjuk oleh Tuhan mereka karena keimanannya, di bawah mereka mengalir sungai-sungai di dalam surga yang penuh kenikmatan.

E. "Sabar" dalam Perspektif Barat 
Kajian literatur Barat berkenaan dengan konsep sabar berkaitan dengan patient dalam pengertian pasien yang mengalami sakit (baik fisik maupun psikologis). Tidak satupun artikel yang berkaitan dengan sabar. Kata kunci patience (kesabaran, kata benda), yang dikaitkan dengan beberapa kata kunci lain, misalnya patience and religion, patience and wisdom, patience and health. 20 artikel (baik artikel psikologi maupun ilmu-ilmu yang terkait) yang di dalamnya memuat kata patience, yaitu: Agte \& Chiplonkar (2007), Al-Hooli \& Al-Shamari (2009), Akano (2003), Bussing dkk. (2007), Chaudry (2008), Colling, (2004), Fetzer (2004), Goral (2010), Hagedoorn dkk. (1999), Kwakkel (2010), Lohne \& Severinson (2003), Marker (2003), Olson, dkk. (2006). O'Malley, dkk. (2010), Ranjbarian, dkk. (2010), Schout, dkk. (2009), Sholders (2000). Smith, dkk. (2005), dan Sparrow (2005).

Artikel-artikel sebagaimana tersebut diatas menyebutkan kata patience dalam konteks yang berbeda-beda, antara lain dalam konteks pendidikan, agama, spiritualitas, wisdom dan konteks kesehatan. Sebagian besar artikel-artikel tersebut hanya mencantumkan kata patience secara sepintas saja. Hanya ada tiga artikel yang tidak hanya mencantumkan kata patience, tetapi tidak membahasnya secara detail. Analisis ketiganya dijabarkan sebagai berikut;

Pertama, artikel yang ditulis oleh Agte \& Chiplonkar (2007). Artikel ini sebenarnya merupakan hasil penelitian yang mengkaji masalah nutrisi dan berbagai jenis makanan dalam perspektif tradisi Yoga di India. Hal yang menarik, artikel tersebut menyebutkan bahwa jenis makanan ternyata mempunyai pengaruh terhadap karakter dan kondisi kejiwaan seseorang.

Kedua, artikel yang ditulis oleh Bussing, Ostermann, \& Matthiessen (2007). Artikel ini menjelaskan tentang sebuah instrument yang digunakan untuk mengukur spiritualitas. Dalam konsep ini spiritualitas terdiri dari tujuh aspek, yaitu: 1) Prayer, Trust in God and Shelter; 2) Insight, Awareness and Wisdom; 3) Transcendence Conviction; 4) 
Compassion, Generosity, and Patience; 5) Conscious Interactions; 6) Gratitude, Reverence, and Respect Equanimity.

Konsep patience ditulis oleh Al- Hooli \& Al-Shamari (2009) yang mengkaji tentang proses belajar mengajar moralitas melalui kurikulum di tingkat Taman Kanak-kanak di Kuwait. Dengan menggunakan instrument the Kindergarten Moral Value Questionnaire (KMVQ), ${ }^{16}$

Sabar (patient dan patience) sebagaimana yang telah dijelaskan dalam tulisan ini, meski pun tidak sama persis, tetapi dapat didekati dan dibandingkan dengan menggunakan beberapa konsep dalam literatur psikologi barat.

\section{Self-control}

Topik tentang self control atau kontrol diri merupakan aspek psikologis yang banyak dikaji dalam psikologi pada tahun 1980-an sebagai salah satu aspek kepribadian. ${ }^{17}$ Psikologi barat, dengan demikian telah lama melakukan kajian terhadap konsep kesabaran, meski menggunakan terminologi berbeda, self control. Self control atau kontrol diri, sebagaimana dikemukakan oleh Averill adalah variabel psikologis yang mencakup kemampuan individu untuk memodifikasi perilaku, kemampuan individu dalam mengelola informasi yang tidak penting atau penting dan kemampuan individu untuk memilih suatu tindakan yang diyakininya. $^{18}$

Konstruk sabar dalam Islam, pada tulisan ini secara umum tercakup dalam terma ini. Secara substansial, sabar terkait erat dengan kontrol diri seseorang dalam menghadapi beragam objek yang tidak menyenangkan.

${ }^{16}$ Selengkapnya bisa dilhat ${ }^{16}$ Subandi, Sabar: Sebuah Konsep Psikologi, Fakultas Psikologi, Universitas Gadjah Mada dalam Jurnal Psikologi, Volume 38, No. 2, Desember 201l: 215 - 227 2011, h. 224

${ }^{17}$ Subandi, "Sabar: Sebuah Konsep Psikologi", dalam jurnal Psikologi Vol. 38. No. 2,

${ }^{18}$ Ririn Anggreini, Sulis Mariyanti, "Hubungan Antara Kontrol Diri dan Perilaku Konsumtif Mahasiswi Universitas Esa Unggul”, dalam jurnal Psikologi, Vol. 12, No. 1, 2014, h. 35. 


\section{Resiliensi}

Resiliensi atau ketabahan sering didefiniskan sebagai kemampuan adaptasi, koping, menghadapi kesulitan dan bangkit kembali dari situasi yang sulit. ${ }^{19}$ Al Siebert mendefinisikan resiliensi sebagai kemampuan individu untuk bangkit kembali dari keterpurukan yang terjadi dalam perkembangannya. Awalnya mungkin ada tekanan yang mengganggu. Namun orang-orang dengan resiliensi yang tinggi akan mudah untuk kembali ke keadaan normal. Mereka mampu mengelola emosi mereka secara sehat. Mereka punya hak dan berhak untuk merasa sedih, marah, merasa kehilangan, sakit hati dan tertekan tetapi mereka tak membiarkan perasaan itu menetap dalam waktu lama. Mereka cepat memutus perasaan yang tidak sehat, yang kemudian justru membantunya tumbuh menjadi orang yang lebih kuat. ${ }^{20}$ Mengahadapi musibah bencana alam, misalnya. Orang yang sabar dalam arti ini akan segera bangkit dan menghadapinya dengan lebih baik.

\section{Perseverence}

Duckworth menemukan bahwa kegigihan, keuletan (perseverance) merupakan salah satu karakter kepribadian yang sangat dibutuhkan dalam mencapai suatu tujuan jangka panjang. ${ }^{2 l}$ Dalam Islam, sabar dalam menjalani proses pendidikan dapat dijadikan sebagai contoh. Siapa yang tidak sabar menghadapi pahitnya belajar, maka harus bersabar menelan pahitnya kebodohan. Metamorfosis ulat menjadi kupu-kupu seringkali digunakan untuk menggambarkan makna sabar dalam arti perseverance.

\section{Acceptence}

Acceptance, yang selalu dikaitkan dengan self-acceptance. Makna yang terkandung mempunyai kemiripan dengan kesabaran dalam Islam, yaitu sejauh mana seseorang mampu untuk menerima

\footnotetext{
${ }^{19}$ Subandi, “Sabar: Sebuah Konsep...”, h. 224.

${ }^{20}$ Umi Rahimah, "Resiliensi dan Sabar sebagai Respon Pertahanan Psikologis dalam Menghadapi Post-Traumatic" dalam Jurnal Ilmu Dakwah, Vol. 6, No. 20, 2012, h. 318-319.

${ }^{21}$ Subandi, "Sabar: Sebuah Konsep...". h. 224.
} 
keadaan dirinya. ${ }^{22}$ Dalam konteks budaya Timur, termasuk Indonesia penerimaan diri dapat berarti menerima takdir Tuhan dan menerima segala sesuatu yang tidak bisa dirubah. Konsep psikologis yang dekat dengan kategori ini adalah konsep 'kematangan emosi' (emotional maturity) maupun kematangan pribadi.

${ }^{22}$ Subandi, “Sabar: Sebuah Konsep...”. h. 225. 


\section{Catatan Akhir}

Sabar merupakan perwujudan dari sikap ketabahan seseorang dalam menghadapi sesuatu yang Allah SWT timpakan kepada seorang manusia. Bentuk dari aplikasi kesabaran dapat dicerminkan dalam sabar dalam ketaatan kepada Allah SWT. Merealisasikan ketaatan kepada Allah, membutuhkan kesabaran, karena secara tabiatnya, jiwa manusia enggan untuk beribadah dan berbuat ketaatan

Konsep sabar dalam al-Qur'an memiliki makna yang beragam, tergantung pada objek atau sesuatu yang dihadapi. Keragaman arti tersebut adalah : 1) Ketabahan menghadapi musibah, disebut sabar; 2) Kesabaran menghadapi godaan hidup nikmat disebut mampu menahan diri (dhobith an nafs); 3) Kesabaran dalam peperangan disebut pemberani (syuja'ah); 4) Kesabaran dalam menahan marah disebut santun (hilm); 5) Kesabaran dalam menghadapi bencana yang mencekam disebut lapang dada; 6) Kesabaran dalam mendengar gosip disebut mampu menyembunyikan rahasia; 7) Kesabaran terhadap kemewahan disebut zuhud; 8) Kesabaran dalam menerima yang sedikit disebut kaya hati (qana'ah).

Konsep-konsep kesabaran dalam al-Qur'an di atas, memiliki kemiripan dengan beberapa konsep dalam literatur psikologi barat, yaitu Self-control, Resiliensi, Perseverence, Acceptence. 


\section{Daftar Rujukan}

Abu Thalib al-Makki, Qauth al-Qulub, Cairo: Dar al-halabi, t.th.

Ahmad Mubarok, Psikologi Qur'ani, Jakarta: Pustaka Firdaus, 2001

Al-Gazali, Ihya 'Ulum ad-Din, Beirut: Dar Ma'rifah, 1990

Ar-Raghib al-Ashfahani, Mufradât al-Fâdz al-Quran, edisi. Shafwan Adnan Dawudi, Damsykus: Dar al-Qalam,1992 M/1412 H

Hamka Hasan, "Hakikat Sabar dalam Al-Qur'an (Kajian Tematik dalam Surah al-

Baqarah), dalam Jurnal Bimas Islam, Vol. 6 No. 2, 2013, h. 215, 232.

Ibn Faris, Mu'jam Maqâyîs al-Lughah, Beirut: Dar al-Fikr, t.th

Ibnu al-Qayyim Al-Jauziyyah, alihbahasa oleh A.M. Halim 'Uddatu Ash-Shabirin wa

Ibn Qayyim, Madarij as-Salikin, Cairo: Dar Salam, t.th

Muhammad Fuad Abdul Baqi, al-Mu'jam al-Mufahras li Alfadz al-Qur'an al-Karim, Cairo:

Dar al-hadits, 1364

Quraish Shihab, Tafsir al-Amanah, Indonesia: Pustaka Kartini, 1992 M/1413 H

Subandi, Sabar: Sebuah Konsep Psikologi, Fakultas Psikologi, Universitas Gadjah Mada dalam Jurnal Psikologi, Volume 38, No. 2, Desember 2011: 215 - 227

Ririn Anggreini, Sulis Mariyanti, "Hubungan Antara Kontrol Diri dan Perilaku Konsumtif Mahasiswi Universitas Esa Unggul”, dalam jurnal Psikologi, Vol. 12, No. 1, 2014

Umi Rahimah, "Resiliensi dan Sabar sebagai Respon Pertahanan Psikologis dalam Menghadapi Post-Traumatic" dalam Jurnal Ilmu Dakwah, Vol. 6, No. 20, 2012 Subhan El Hafiz, Psikologi Kesabaran, Buletin Konsorsium Psikologi Ilmiah Nusantara, ISSN 2477-1686, Vol. 1., No. 2, November 2015 